\title{
GLACIAL GEOLOGICAL EVIDENCE FOR THE MEDIEVAL WARM PERIOD
}

\author{
JEAN M. GROVE \\ Girton College, Cambridge, U.K. \\ and \\ ROY SWITSUR \\ Wolfson College, Cambridge, U.K.
}

\begin{abstract}
It is hypothesised that the Medieval Warm Period was preceded and followed by periods of moraine deposition associated with glacier expansion. Improvements in the methodology of radiocarbon calibration make it possible to convert radiocarbon ages to calendar dates with greater precision than was previously possible. Dating of organic material closely associated with moraines in many montane regions has reached the point where it is possible to survey available information concerning the timing of the medieval warm period. The results suggest that it was a global event occurring between about 900 and 1250 A.D., possibly interrupted by a minor readvance of ice between about 1050 and 1150 A.D.
\end{abstract}

\section{Introduction}

During the last few hundred years glaciers in both hemispheres expanded. Their maximal positions can be identified by the moraines they left behind a kilometre or two away from the present retreating ice fronts. Moraines formed by earlier periods of enlargement can, given favourable circumstances, be dated. Dating of organic material above a moraine provides a minimal age for its formation. Material from beneath it can provide a maximum age. A sample from within a moraine may give a closer approximation of the time of formation. Time lags almost always occur between moraine formation and the accumulation or deposition of the dated material.

It can reasonably be hypothesised that the Medieval Warm Period (MWP) should be bracketed by the dates of the moraines formed during the periods of enlargement which preceded and followed it. In Europe and in some other parts of the world glacial expansion is known to have taken place between 800 A.D. and 900 A.D. There is at present no commonly accepted name for this episode. The most recent period of glacial expansion, during which glaciers remained more advanced than in the mid to late twentieth century, occurred in the six centuries between about 1250-1300 A.D. and 1850-90 A.D. The last four centuries of this period are widely known as the Little Ice Age (LIA). Some find it more appropriate to apply the term LIA to the whole period from the thirteenth to the nineteenth centuries, especially as although it covered two advance phases of approximately 
equal magnitude, conditions between them did not revert to those obtaining before 1300 A.D. In this paper the broader definition of the LIA, covering 1250-1300 A.D. to $1850-90$ A.D., is adopted.

Recently some doubt has been cast on the utility of retaining the term LIA (Bradley and Jones, 1992a, b), because recent centuries are now known to have been characterised by 'complex climatic anomalies, with both warm and cold episodes which varied in importance geographically' (Bradley and Jones, 1993), changes in the general circulation resulting in positive anomalies in some areas at times when negative anomalies are recorded elsewhere. However when the many individual proxy climatic records brought together in 'Climate since A.D. 1500' (Bradley and Jones 1992b) are combined, it is revealed that in the northern hemisphere temperatures from 1400 A.D. to 1910 were between 0.5 and $1.5^{\circ} \mathrm{C}$ below those experienced during the twentieth century, except for the last quarter of the fifteenth century, the first half of the sixteenth century and the latter half of the eighteenth century (Bradley and Jones, 1993). (The southern hemisphere proxy data presently available is insufficient to support generalisation.) This is very much what was to be expected from the glacial evidence, and justifies the continued use of the term LIA to describe a period during which the fronts of enlarged glaciers oscillated around forward positions.

In practice it is often possible to obtain only a maximum or only a minimum date for the formation of a particular moraine, but by now a considerable amount of information is none the less available. It is intended here to survey the existing evidence which should, at least in theory, serve to reveal whether the MWP was global in extent, and whether it occurred at the same time in different regions.

Certain difficulties and limitations occur in practice, firstly with regard to dating. Apart from very recent features, about which historical data is available, this depends on dendrochronology, lichenometry or radiocarbon. Obtaining the age of the oldest trees or tree growing on a moraine may well not provide a minimal age anywhere near the real age. The oldest tree may not be found. It may anyway not belong to the first generation to grow on the moraine. The unknown lag between moraine formation and tree growth may be very long indeed.

\section{Dating Methods}

\subsection{Lichenometry}

Lichenometry is dependent on the hypothesis that the largest lichen growing on a surface is the oldest, and that if the growth rate for a given species is known, the maximum lichen size will give a minimum age for the substrate, the rate being unaffected by changes in climate. Lichenometry can be accurate to within \pm 5 years or so for the last 200 years, given unusually favourable circumstances (Porter, 1981). Acceptable accuracy may be obtained for considerably longer periods, but lichenometry cannot be considered useful for the MWP. Studies based on lichenometric dating will not be discussed in this paper. 


\subsection{Radiocarbon Dating}

The use of radiocarbon analysis depends upon the existence and discovery of suitable materials for dating. Carbon dating of mature paleosols involves the possibility of substantial errors (Matthews, 1984, 1985). If young soils are dated, separation of the humic acids from the humins, allows the necessary evaluation of the extent of contamination. It is suggested that the humic acid fraction may be taken to give the younger age, representing the end of soil formation. Macro-residuals, such as lichens, may give an approximation of the beginning of soil formation, following an earlier cold phase (Röthlisberger and Geyh, 1985a).

There are also potential difficulties with dating peat of any appreciable age. In the upper few centimetres, the acrotelm, the peat has an open structure and rapid and almost complete oxidation occurs, but in the lower, more compacted catatelm the breakdown becomes very slow in the prevailing conditions of oxygen deficiency. Decomposition may take place under these conditions through the agency of sulphur-fixing bacteria, hence giving rise to the characteristic fetid smell of such deposits. The decomposition products include complex fulvic and humic acids of various high molecular weights, and since the reactions do not proceed to completion, isotopic fractionation takes place. Slow compaction of the peaty residue accompanies the chemical changes. The residual humins represent a peat fraction that is more resistant to decomposition. Since both humic acids and fulvic acids are to some extent soluble forming colloidal solutions, these may be transported by water movement and possibly left as contamination of a different age elsewhere in the deposit. This is more likely to occur in deep or ancient deposits. Recent work on dating the various fractions from blanket peat has demonstrated inconsistencies with the humic acids sometimes younger and sometimes older than the humin fraction and differing in age by up to several centuries. Such age differences are much greater than might be expected from uncertainties of the technique. Hence, for moraine dating, wood, moss or thin peats would appear to provide a safer basis for dating.

\section{Calibration}

A problem with radiocarbon dating of Holocene samples is that radiocarbon years and sidereal years are rarely of the same length. This phenomenon is caused by the secular variation of the concentration of atmospheric radiocarbon. It was clearly demonstrated by Willis et al. (1960), from measurements on small groups of tree rings of known dendro-date, taken from a Giant Redwood, that during the Christian era the radiocarbon concentrations had not been constant, as required by the simple radiocarbon dating theory of Libby, but had varied by $1 \%$ or more, causing the radiocarbon age of samples to differ from calendar date by 50 to 100 years. Similar research by other workers on long-lived species, such as Bristlecone Pine (Suess, 1970), showed that the effect became more pronounced for earlier periods, and that 
a discrepancy of almost a millennium occurred around $6000 \mathrm{BP}$ In order to obtain results compatible with calendar years it has thus become necessary to calibrate the radiocarbon time scale using dendrochronologically dated timber. Many calibration studies have been carried out during the past three decades and the most recent measurements have been made with higher accuracy and greater precision than those of earlier years. The latest work has invoved oak and Douglass pine and the combined results presented by Pearson, Stuiver and their co-workers have been accepted as the best possible at the present time. However the data as published (Stuiver and Pearson, 1986, 1993 and others) are not ideal for use by hand and do not allow the full information to be extracted easily, and so several attempts have been made to adapt their use to computer manipulation. A comparison of some of these different techniques was given at the Dubrovnik Radiocarbon International Conference (Aitchison et al., 1989). The general agreement between the algorithms was good and the discrepances amongst the techniques were only of a few years.

Measurements of radiocarbon activity are essentially of a statistical nature, being repeated timed counts of nuclear disintegrations of a specified energy range during given time. The results of these may be represented by a distribution that has a well defined mean value and standard deviation. A similar distribution is obtained for the radioactivity of the international standard, NBS oxalic acid, which represents the activity of the modern pre-industrial revolution atmosphere. These data are further corrected for instrumental blanks and other laboratory errors and for the isotopic fractionation of the sample material. Finally the activity is converted by a logarithmic transformation to a conventional radiocarbon age, $\mathrm{BP}$, (before present) which is based on the zero year of A.D. 1950 and the Libby half-life for the radiocarbon isotope, of 5568 years. In the recent part of the time scale, the age probability has a Gaussion distribution with a mean age and uncertainty. The uncertainty is conventionally represented by a \pm term at a probability of $68 \%$, which implies a single standard deviation of the disintegrated statistics. It has been found that this value tends to underestimate the true uncertainty of the age and to compensate for this another multiplying factor (ca. 1.1 to 2.5 for example), is often used. Unfortunately such factors differ for each radiocarbon laboratory, each instrument in that laboratory and probably with time, and this has the effect of smearing the radiocarbon age over a greater period of time. The measured, known-date calibration points, of course, are all similar Gaussian distributions and the shape of the calibration curve itself is the envelope of these distributions. In practice the curve is obtained by computer fitting a curve to the individual points, normally using a spline function.

In order to calibrate a particular conventional radiocarbon age, one technique is to divide the appropriate portion of the calendar axis into small sections of say 20 years. The probability of the true-date falling into each of these sections is evaluated by the interaction of the appropriate Gaussian distribution of the radiocarbon age with that of the calibration curve. The probability distribution for the calendar range is thus constructed on the calendar axis, conveniently in the form of a histogram. 
The extreme ends of the distribution represent the calibrated range for that date. The distribution along the calendar axis is not a symmetrical Gaussian unless the calibration curve is a straight line. In general this is not the case because of the wiggles of the calibration curve.

\section{Examples of Calibration}

The process of calibration may be followed for different cases in Figures $1 \mathrm{a}$ and $1 \mathrm{~b}$, for two radiocarbon ages used in this survey, which show quite different effects on the date range. In these the ordinate represents the radiocarbon age (BP) axis and the abscissa is the axis for the calendar date-ranges. The internationally accepted notation for this axis is cal.A.D. (or cal.B.C. or cal.BP). The dashed straight line sloping from left to right across the diagram represents the line of equivalence of radiocarbon ages and calendar dates. The winding curve sloping downwards left to right represents the calibration curve and it will be seen how his moves about the line of equivalence. This calibration curve is intersected by three horizontal lines which represent the conventional radiocarbon age. The middle line is the central age, and the other two indicate the uncertainty equivalent to the one standard deviation limits of the statistics producing this age. The interaction between these produce the shaded histogram drawn on the calendar-date axis. The heights of the histogram rectangles are proportional to the probability (indicated on the right hand scale) of the calibrated date being at that position. In the computation the extremes of the histogram represent $95 \%$ confidence limits for the calibrated date. It is customary to indicate the conventional radiocarbon measurements by the term age and the calibrated version by date-range.

The two diagrams show well the different effects of the shape of the calibration curve as well as the age uncertainty on the calibrated date-range. In Figure 1a the intersection of the calibration curve and the radiocarbon age line occurs where the slope of the calibration curve is at a high angle to the calendar date axis. The standard deviation also is quite small, so that the probability histogram extends only a short distance along the calendar axis. This leads to the calibrated date having a smaller time range than the original radiocarbon age. In this instance, at $68 \%$ confidence limits, the radiocarbon age spans 90 years (765 to $675 \mathrm{BP}$ ), whereas the calibrated date-range is only 20 years and may be pinpointed to between 1250 and 1270 cal.A.D. By contrast however in Figure $1 \mathrm{~b}$ the conditions are quite different; at the intersection the calibration curve is almost parallel to the calendar axis, and this, together with the large uncertainty of the age, produces a probability histogram with a wide range. The histogram has several relatively high peaks indicating multiple valid possibilities for the correct date. The $68 \%$ confidence limits here are necessarily wider, at 245 years, than the limits of the radiocarbon age, 200 years. The value of the histogram height helps to interpret the likelihood of any particular date being correct. However in our survey paper the data, from many sources, are of necessity of varying precision and reliability and do not provide the full pattern 


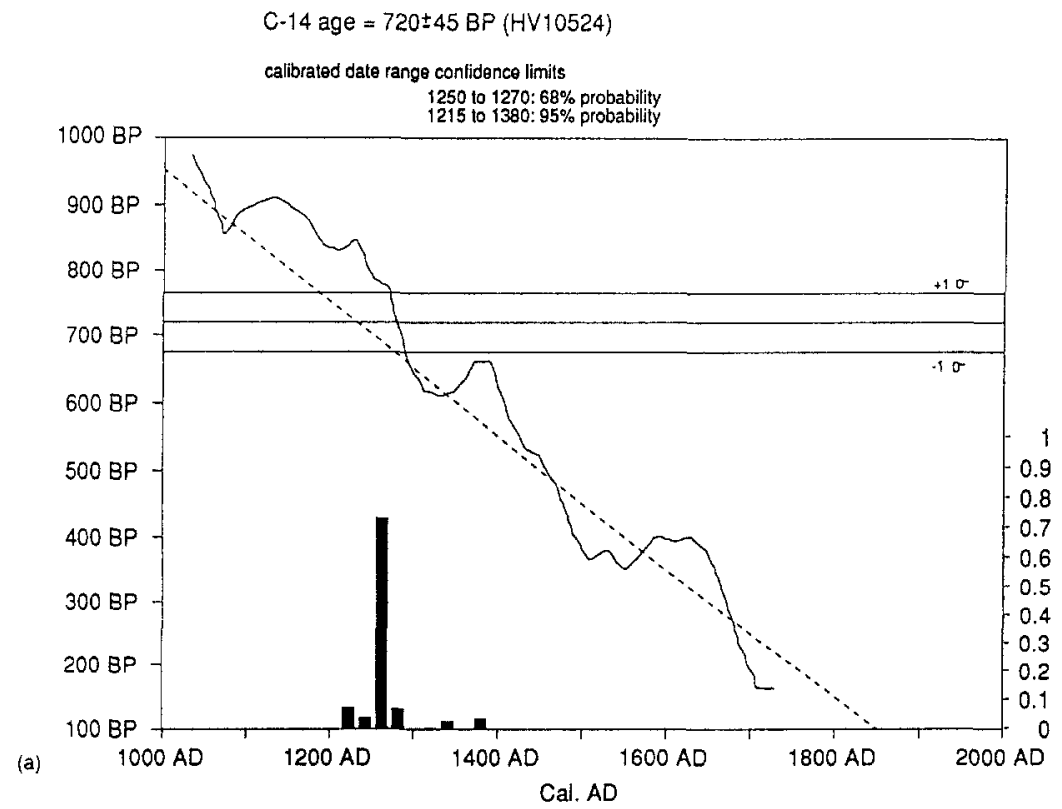

C-14 age $=905 \pm 100 \mathrm{BP}(18441)$

calibrated date range confidence limits

1000 to $1245: 68 \%$ probability
880 to $1270: 95 \%$ probability

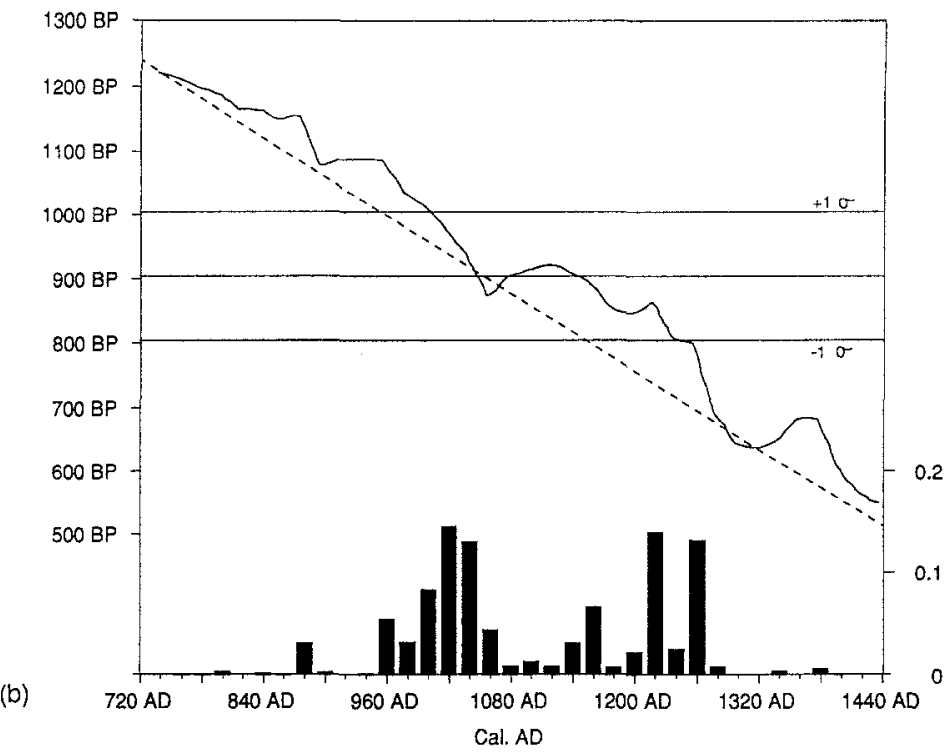

Fig. 1. Examples of calibration of radiocarbon years to calendar years: (a) Hv-10524, a sample from a moraine of the Balfour Glacier, Westland, New Zealand; (b) I-8441, a sample from peat overridden by the Quelcaya Icecap, Peru. 
of glacier frontal oscillations, so the detailed aspect of the calibration procedure will not be pursued further. The calibrated dates in the tables are given in terms of the date-range falling within the $68 \%$ (1 sigma statistics) probability range. The dated evidence relating to glacier fluctuations has accumulated from many parts of the world to an extent which now makes it worthwhile to attempt to assess its value in the context of the Medieval Warm Period.

\section{The Distribution of the Data and Its Implications}

Difficulties of dating are not the only ones. The major problem caused by the distribution of investigations must not be overlooked. The bulk of detailed research has been carried out in Europe. This has revealed that the commonly held view that the Little Ice Age (LIA) advances were everywhere the most extensive is not correct. In the European Alps the ice reached very similar positions several times during the Holocene, causing deposits to be set down very close to each other or actually on top of each other. Only very intensive field investigations have served to reveal the complexity of Holocene glacial history. While it should not be assumed that these relationships between glacial phases in the last few thousand years are to be expected in other regions, it certainly cannot be taken for granted that advances elsewhere were well separated spatially. Adequate investigations must therefore be intensive. But regions such as the southern Andes or the Canadian Rockies contain thousands of glaciers which have never been examined. In Alaska it is, very naturally, the major ice streams which have attracted attention, yet most of these either have tongues prone to float, or are subject to surging. Such glaciers may exhibit substantial fluctuations unconnected with minor or intermediate scale changes in climatic conditions. Although they also react to climatic circumstances (Mann, 1986) evidence from such glaciers will not be considered here. Dates which have had to be corrected for carbon deficiency in Antarctic sea water by several hundred years, such as those from the South Shetland Islands (Clapperton and Sugden, 1989) are also not discussed.

Key evidence from regions in Eurasia, North and South America, and New Zealand (see Figure 2) will be presented in the form of tabulated graphs, showing both conventional radiocarbon ages, as originally published, with their laboratory errors, and their calendar equivalents at 68\% probability (Stuiver and Pearson, 1986).

\section{The European Alps}

The best known Holocene glacial history is that of the Alps, particularly the Swiss Alps, resulting in large part from the work of a group of researchers at the Geographical Institute of Zürich University. They had the advantage of the discovery of much fossil wood amongst the glacial deposits. (Between 1970 and 1975, thirty pieces were found within $300 \mathrm{~m}$ of the Zmutt glacier alone). The numbers of 


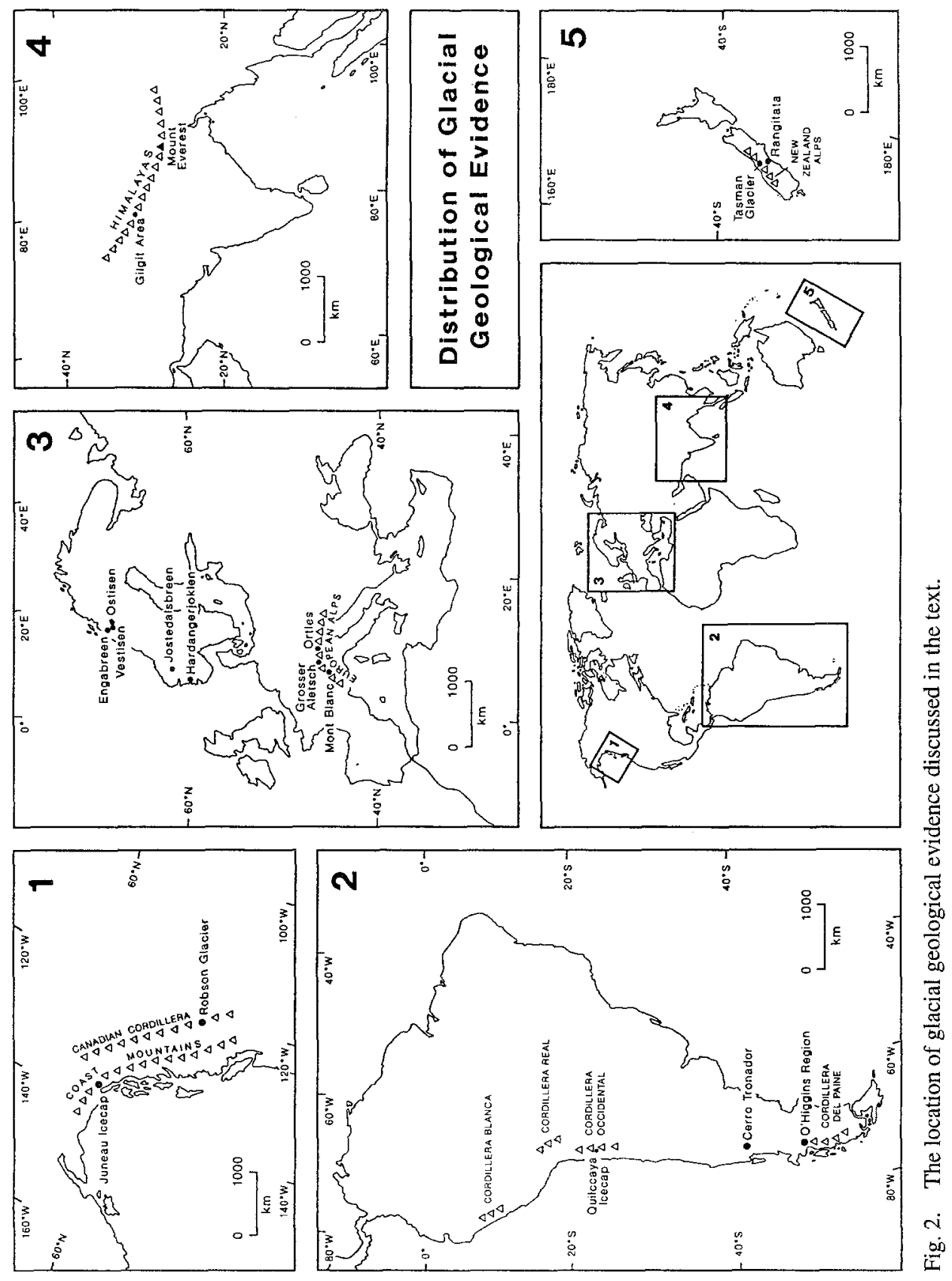


rings in tree trunks overridden by ice, it was realised, could be used to give minimum values for the length of periods between advances. By 1980, Röthlisberger and his associates had obtained some 87 dates relevant to the Holocene sequence in the canton of Valais alone, indicating that the glaciers had advanced to very similar positions in Medieval times and in the LIA, but the abundance of dates around $1000 \pm 100 \mathrm{BP}$ and their overlap underlined the difficulties of interpretation (Röthlisberger et al., 1980), and suggested the potential importance of combining glacial and dendroclimatological evidence.

One of the earlier discoveries was that of wood fragments, which had been buried by the Aletsch Glacier (Oeschger and Röthlisberger, 1961). It was concluded that the trees had been covered by an ice advance about 1200 A.D., nearer the end of the MWP. Retreat of the tongue during the twentieth century uncovered not only the stumps of trees growing in situ and roots, but also the remains of an irrigation channel, the Oberriederin Bisse, which is recorded as abandoned in 1385 (Kinzl, 1932). Lamb (1965) who first advanced the idea of the MWP, argued that this bisse (a bisse is an irrigation channel, essential for agriculture in the dry climate of the Valais), had been constructed during the warm period in a position which became untenable when the climate changed and the glacier expanded (Lamb, 1988).

It was the Aletsch which was to furnish evidence allowing the most detailed reconstruction of glacier oscillations before, during and after the MWP. Holzhauser $(1984,1988)$ has made intensive studies of the Aletsch deposits and has been able to reconstruct a remarkably complete record of the fluctuations of its tongue for the last three thousand years (Table I, Figure 3). This shows that the MWP was preceded by a rapid advance of the ice, lasting about a century which, around 850-900 A.D., brought its front close to its LIA maximum. Retreat of the ice between 900 A.D. and 1000 A.D. was almost as swift. The MWP was terminated by an equally rapid advance culminating about 1350 A.D. But climatic conditions were not uniform throughout the MWP. The Aletsch readvanced again from 1050 A.D. to 1150 A.D., to a position about $1.7 \mathrm{~km}$ beyond the current one. The earliest phase of the LIA ended the MWP with an abrupt and substantial advance between 1250 A.D. and 1350 A.D., destroying part of the Oberriederin Bisse. Documentary evidence that the Allalin glacier was also in an extended position in the thirteenth century has also been found (Lütsch, 1926).

The Aletsch reconstruction is exceptionally accurate not only because of the wealth of radiocarbon evidence but also because from 1100 A.D. onwards it is controlled by absolute dating of tree rings from stumps in situ. Additional documentary sources have also been located. Confirmatory evidence of many of its features comes from the Grindelwald, the Rhone and the Unteraar glaciers (Figure 4). The oscillations of a large sample of Swiss glaciers have been observed annually since the late nineteenth century (Grove, 1988). Those of the Aletsch, Grindelwald, Rhone and Unteraar have been in no way exceptional, and their earlier fluctuations may reasonably be taken as representative for the region. Further critical reexam- 
TABLE I: Key dates relating to the glacier oscillations in the Swiss, French and Italian Alps. The numbers at the margin give the laboratory identification number, the $\mathrm{C} 14$ age and the calibrated age for $68 \%$ probability. Horizontal lines represent calibrated dates. The symbol > indicates a maximum date; <indicates a minimum date

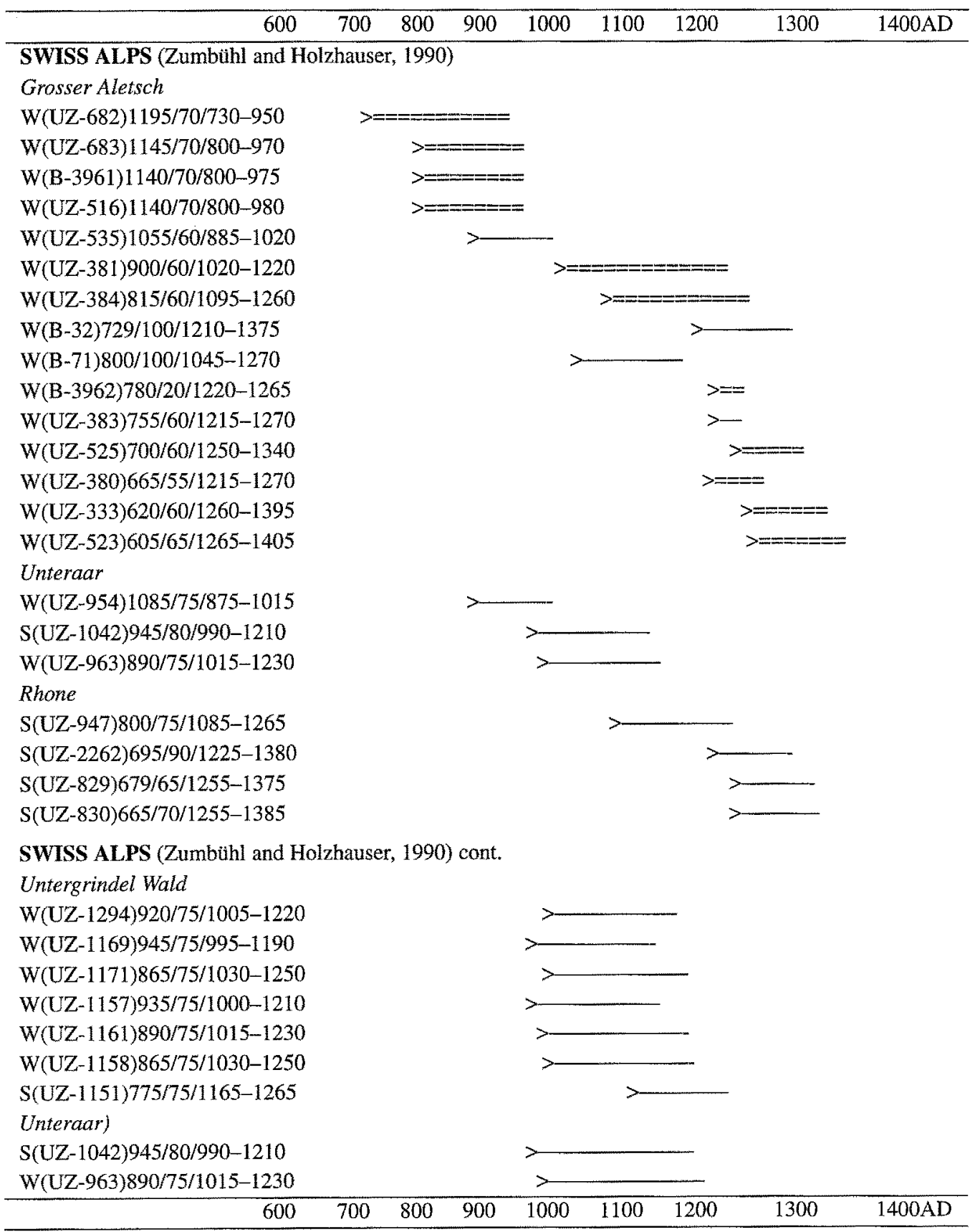


TABLE I: Continued

\begin{tabular}{|c|c|c|c|c|c|c|c|c|}
\hline 600 & 700 & 800 & 900 & 1000 & 1100 & 1200 & 1300 & $1400 \mathrm{AD}$ \\
\hline \multicolumn{9}{|l|}{ FRENCH ALPS } \\
\hline \multicolumn{9}{|l|}{ Trient (Bless, 1984) } \\
\hline \multirow{2}{*}{\multicolumn{9}{|c|}{$\begin{array}{l}S(U Z-233) 825 / 55 / 1065-1260 \\
\text { ITALIAN ALPS }\end{array}$}} \\
\hline & & & & & & & & \\
\hline \multicolumn{9}{|c|}{ Ortles-Cevadale Valtellina Valley } \\
\hline \multicolumn{9}{|c|}{ Zebu and Chedec (Pelfini, unpublished) } \\
\hline S $\quad 945 / 75 / 995-1190$ & & & & & & & & \\
\hline S $\quad 940 / 70 / 1100-1185$ & & & & & & & & \\
\hline \multicolumn{9}{|c|}{ Genova Valley (Aeschlimann, 1983) } \\
\hline$(G X-15138) 1190 / 75 / 725-995$ & & $====$ & $====$ & & & & & \\
\hline \multicolumn{9}{|l|}{ MONT BLANC GROUP } \\
\hline \multicolumn{9}{|l|}{ Miage } \\
\hline$S(U Z-296) 760 / 50 / 1220-1265$ & & & & & & $\longrightarrow<$ & & \\
\hline$S(U Z-334) 690 / 60 / 1250-1350$ & & & & & & & $-<$ & \\
\hline 600 & 700 & 800 & 900 & 1000 & 1100 & 1200 & 1300 & $1400 \mathrm{AD}$ \\
\hline
\end{tabular}

Note: $\mathrm{W}=$ wood, $\mathrm{S}=$ soil, $\mathrm{M}=$ moss, $\mathrm{P}=$ peat, $====$ in situ.

ination of earlier work by the Zürich group is under way and may be expected to amplify the present picture.

Evidence from other parts of the Alps is much more fragmentary, and absolute dates from trees in situ are not, so far, available to reduce the degree of uncertainty involved in the individual radiocarbon results. It is obvious from Table I that less data is forthcoming from the rest of the Alps than from the Aletsch and the other three glaciers discussed already, quite apart from that collected by Röthlisberger from other Swiss glaciers. The fluctuations of Austrian, Italian and French glacier tongues have been in phase with each other since deliberate monitoring began.

There is as yet no direct evidence from the Austrian Alps of the MWP advances in the 12th or 13th centuries, though this is likely to be forthcoming as investigations continue. In the Italian Alps, well-developed soils from under moraines marking the maximum extent of the Chedec and Zebu glaciers, in the Ortles-Cevadale group, have been dated to $945 \pm 75 \mathrm{BP}$ and $940 \pm 70 \mathrm{BP}$ (Pelfini, unpublished). This indicates that the two moraines were deposited after 995-1190 A.D. and after $1100-1185$ A.D. at $68 \%$ probability (Table I). Only the top centimetre was dated in each case. In the Genova valley, the top of a layer of peat underlying a Holocene moraine provides a maximum date for moraine formation of $1190 \pm 75 \mathrm{BP}$ (GX13518), or 725-995 A.D. In the Mount Blanc group a pre-LIA advance followed by recession is indicated by two dates on buried soils of $760 \pm 50 \mathrm{BP}$ (UZ-396) and $690 \pm 60 \mathrm{BP}$ (UZ-334), that is $1220-1265$ A.D. and 1250-1350 A.D., at $68 \%$ probability. A buried soil in the forefield of the Trient (in the Swiss sector of the 


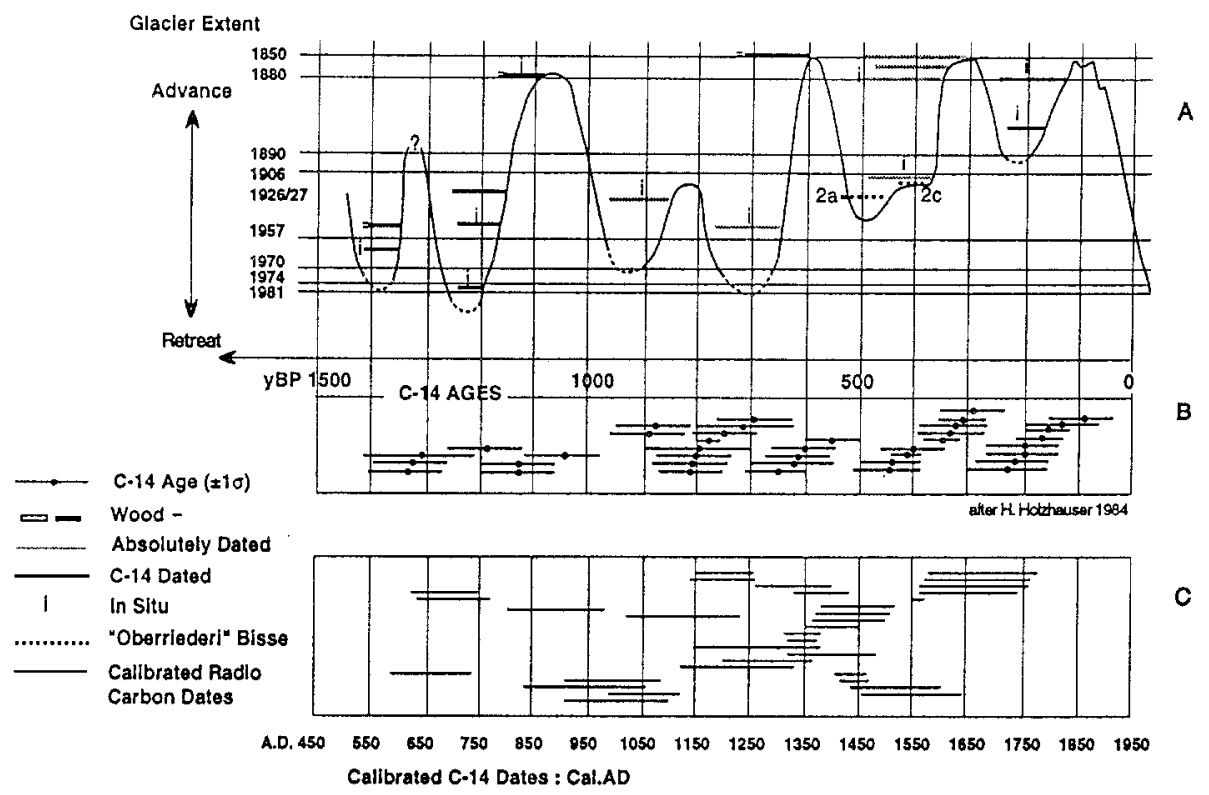

Fig. 3. The oscillations of the Grosser Aletsch Glacier, Switzerland, since 2000 years BP: (A) Oscillations of the glacier since $1500 \mathrm{BP}$, shown in comparison with positions occupied by the ice since $1850 \mathrm{AD}$. The graph was based on a variety of evidence, including the positions of absolutely dated trees in situ, as well as radiocarbon dated samples, many of them also in situ. The great majority were found in lateral positions above the present ice surface. The height above the glacier of the positions where the samples were found formed an essential element of the evidence used in the reconstruction. Most of them were taken from the outer rings of trees which were overrun by the ice. Very full details are recorded in Holzhauser (1984); (B) Conventional radiocarbon ages (BP) as presented in Holzhauser (1984); (C) Calibrated date-ranges (cal. AD) for key samples from the Grosser Aletsch (listed in Table I). During the past few centuries the radiocarbon content of the atmosphere has varied rather widely so that the measurement of the activity of organic samples growing during this period is not a good guide for their age. Even high precision measurements leading to calculations of radiocarbon ages with small uncertainties of the order of 20 years when calibrated produce a wide range of possible calendar dates extending to AD 1950, the zero year of the radiocarbon time scale. Such samples should be reported as modern. For this reason samples with conventional radiocarbon ages of ca 200 years or younger have been omitted from the calibrated section of Figure 2.

Mount Blanc group) dates at $825+50$ BP or 1065-1260 A.D. (UZ-233). None of this evidence is in conflict with better controlled Swiss evidence.

Documentary evidence also provides some support. At the Rutor glacier, floods have occurred when the glacier was in extended positions and formed a dam. The earliest floods seem to have taken place in 1371-1470, and even perhaps as early as 1284 A.D. (Sacco, 1917). Floods definitely occurred in all years around 1594-98 A.D. and later during the LIA proper. The fourteenth century event thus signals that the ice was similarly advanced and that here, at least, the MWP was over. It has also been suggested that it was the bursting of the Lac de Combal, dammed by the extension of the Miage glacier, which caused floods before 1340 A.D. (Rabot, 1902). No indications are available from Rutor of the time when the MWP began. 


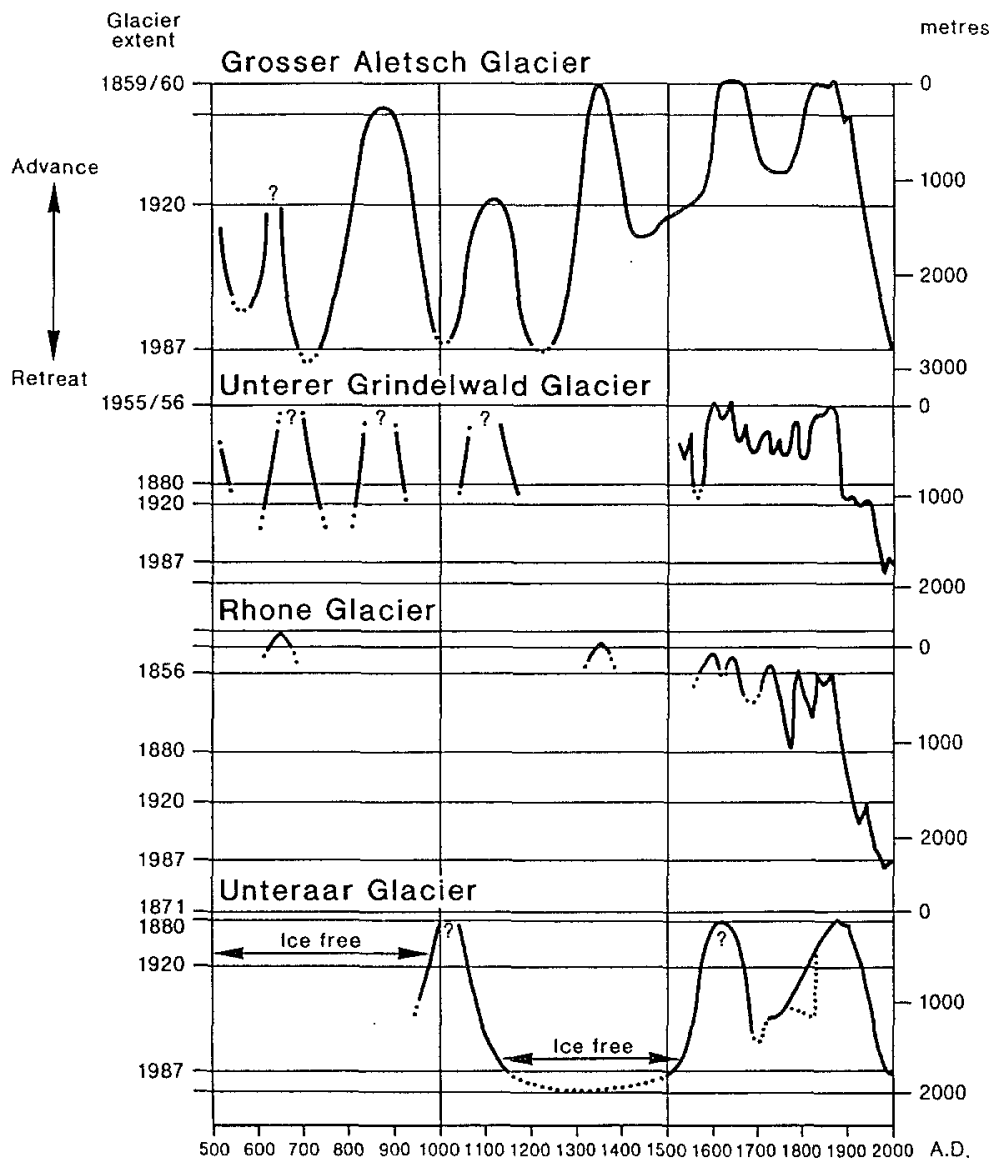

Affer H.J.Zumbüht / H. Holzhauser 1988

Fig. 4. Oscillations of other Swiss glaciers compared with those of the Grosser Aletsch Glacier. (From Holzhauser, 1988).

The most closely dated glacial geological evidence for the timing of the MWP comes from Switzerland. This indicates that the MWP was preceeded by an advance phase culminating between about 850-900 A.D., which brought fronts forward to positions comparable to those of the LIA maxima, that it was interrupted by a brief period of limited glacial expansion, culminating between about 1100 1150 A.D., and that it was terminated by a climatic deterioration which caused fronts to reoccupy advanced positions by about 1350 A.D. On the basis of current knowledge, a European Science Foundation working group on glacier fluctuations recently concluded that the MWP occurred between about 900 A.D. and 1250-1300 A.D. in the European Alps (Grove and Orombelli, in press). 
TABLE II: Key dates relating to the glacier oscillations in Norway and the Himalaya. The numbers at the margin give the laboratory identification number, the $\mathrm{C} 14$ age and the calibrated age for $68 \%$ probability. Horizontal lines represent calibrated dates. The symbol $>$ indicates a maximum date; < indicates a minimum date

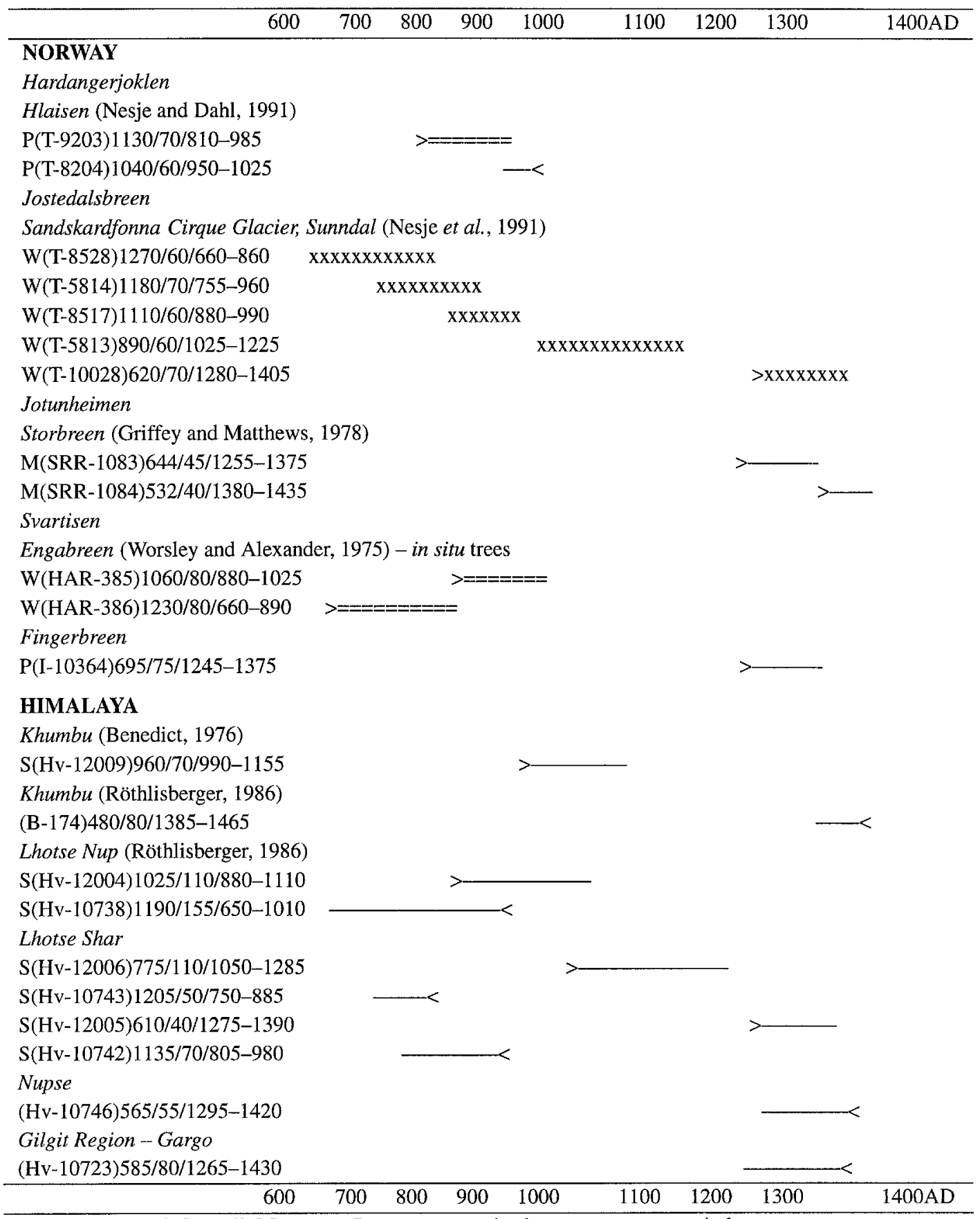

Note: $\mathrm{W}=$ wood, $\mathrm{S}=$ soil, $\mathrm{M}=$ moss, $\mathrm{P}=$ peat, === = in situ, $\mathrm{xxxx}=$ warm period. 


\section{Scandinavia}

If the evidence from the Alps is in general agreement, it is logical to consider next whether the same is true of data from Scandinavia (Table II). Current data is very widely scattered and is not abundant.

Tree stumps have been found in paleosols interlayered with distal glaciofluvial fan deposits at Sandsvora, Sunndalen, at the northern end of Jostedalsbreen. Radiocarbon dates from these organic layers indicate that the Sandskardfonna cirque glacier had either contracted or had disappeared close to $1270 \pm 60 \mathrm{BP}$

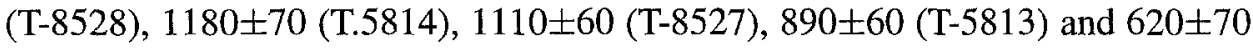
(1280-1405) (Table II). It seems that the glaciation threshold must have been at least $50 \mathrm{~m}$ above its present altitude during intervals when Sandskardfonna was melted away. The youngest of the dates obtained gives a maximum date of 1280 1405 A.D. for the first LIA expansion of the Sandskardfonna cirque glacier (Nesje et al., 1991; Nesje and Rye, 1993).

The forefield of Blaisen, a north-eastern outlet of Hardangerjoklen, $\left(69^{\circ} 33^{\prime} \mathrm{N}\right.$, $7^{\circ} 25^{\prime} \mathrm{E}$ ) has been studied by Nesje and Dahl (1991). A stratigraphic sequence of bluish-grey sand and silt, taken to be of glaciofluvial origin, is interbedded with organic material, deposited during intervals of frontal recession. A thin sand/silt deposit near the top of the studied section lies between peat layers. A sample from the upper part of the underlying peat gives a date of $1130 \pm 70 \mathrm{BP}$ (T-9203) and a maximum age for a short glacial advance preceeding the MWP of $810-985$ A.D. A sample from the overlying peat of $1040 \pm 60 \mathrm{BP}$ (T-8204) provides a minimum date for deposition of the fluvioglacial sediments, which may have occurred at about the same time as the advance of the Aletsch in the mid-MWP, and a maximum but not necessarily close date for later Little Ice Age advances of 950-1025 A.D. Other evidence from southern Scandinavia, coming from the Jotunheimen (Griffey and Matthews, 1978), provides closer dating for advances after the MWP. Moss from underneath a LIA moraine of Storbreen has dates of 664 \pm 45 BP (SRR-1083), and $532 \pm 40$ BP (SRR-1084), giving maximum ages of 1255-1375 A.D. and 13801435 A.D. respectively, fitting well with the results from Sandskardfonna.

While no unequivocal documentary evidence of the MWP has been found in southern Norway, it has been suggested that severe damage to farms in Olden and Loen parishes, situated immediately to the north of Jostedalsbreen in the first half of the fourteenth century, may well have been associated with glacial expansion and associated increases in landslides and floods (Grove, 1985).

A sample from the top $2 \mathrm{~cm}$ of peat under a moraine fronting Fingerbreen, an eastern outlet of Ostisen, in the Svartisen region of northern Norway, of $695 \pm 75$ BP (I-10364) indicates that deposition took place after 1245-1375 A.D. (Karlén, 1988). The closest dates available from Norway at present are those from in situ alder of 1060 $\pm 80 \mathrm{BP}$ (HAR-385) and a willow stump, also in situ, 1230+/080 BP (HAR-386), both near Engerbreen (Worsley and Alexander, 1975). These dates of 
880-1025 A.D. and 660-890 A.D. for glacial advance preceeding the MWP are not in conflict with the Alpine reconstruction.

Although the Scandinavian evidence is both fragmentary and scattered most of that which is available so far suggests that glacial history during the last millennium was probably roughly similar to that in the Alps. But it must be noticed that the Sandskardfonna evidence is interpreted by Nesje and Rye as showing that while there were small bursts of glacial activity alternating with warmer periods of little or no such activity from around $660 \mathrm{BP}$ onwards until after 1280-1405 A.D. when the first LIA advance began, no clear evidence of major glacial expansion before the MWP was forthcoming. This suggests the possibility of a real difference in conditions between southern Norway and the north of the country, where the Fingerbreen data seems to fit with that from Switzerland. More investigations are needed if a more definitive view is to be obtained.

\section{The Himalaya}

Dating of LIA initiation in the Mt. Everest region (Table II) depends on studies of the moraines of only a very few glaciers. The stratigraphic relationships of some of the radiocarbon dated samples which have been collected are somewhat uncertain (Williams, 1983), and have therefore not been included. Röthlisberger (1986) examined the moraines of 16 glaciers in the Himalaya, selecting only those comparable in size with those in the Alps. Dates from paleosols amongst the moraines of three glaciers in the Mt. Everest area and one in the Gilgit region are shown on Table II (Benedict, 1976; Röthlisberger and Geyh, 1985a; Röthlisberger 1986). These provides evidence of moraine formation after 1050-1285 A.D. and before 1110 A.D. The moraine formed after 1050-1285 A.D. could have been contemporary with the minor advance during the MWP in the Alps, but could also belong to the first LIA advances, which were evidently under way between 1265-1465 A.D. These few dates, all on soil, are inadequate guides to the timing of glacial events in the Himalaya, which contains the largest ice-covered area outside the Polar regions, but do not in themselves indicate any significant difference from those in the European Alps.

\section{North America}

\subsection{Alaska}

The best known glaciers in this enormous region are either surging or tidewater glaciers and so dating their fluctuations is not a reliable guide to the timing of the MWP. Röthlisberger investigated moraines on a number of forefields and added considerably to knowledge of land-based glaciers (Röthlisberger and Geyh, 1986). Dates from several moraine sets around the Juneau Icefield are shown on Table III. In situ stumps on the side of a nunatak of the Llewellyn Glacier indicate kill 
TABLE III: Key dates relating to the glacier oscillations in North America. The numbers at the margin give the laboratory identification number, the $\mathrm{C} 14$ age and the calibrated age for $68 \%$ probability. Horizontal lines represent calibrated dates. The symbol $>$ indicates a maximum date; $<$ indicates a minimum date

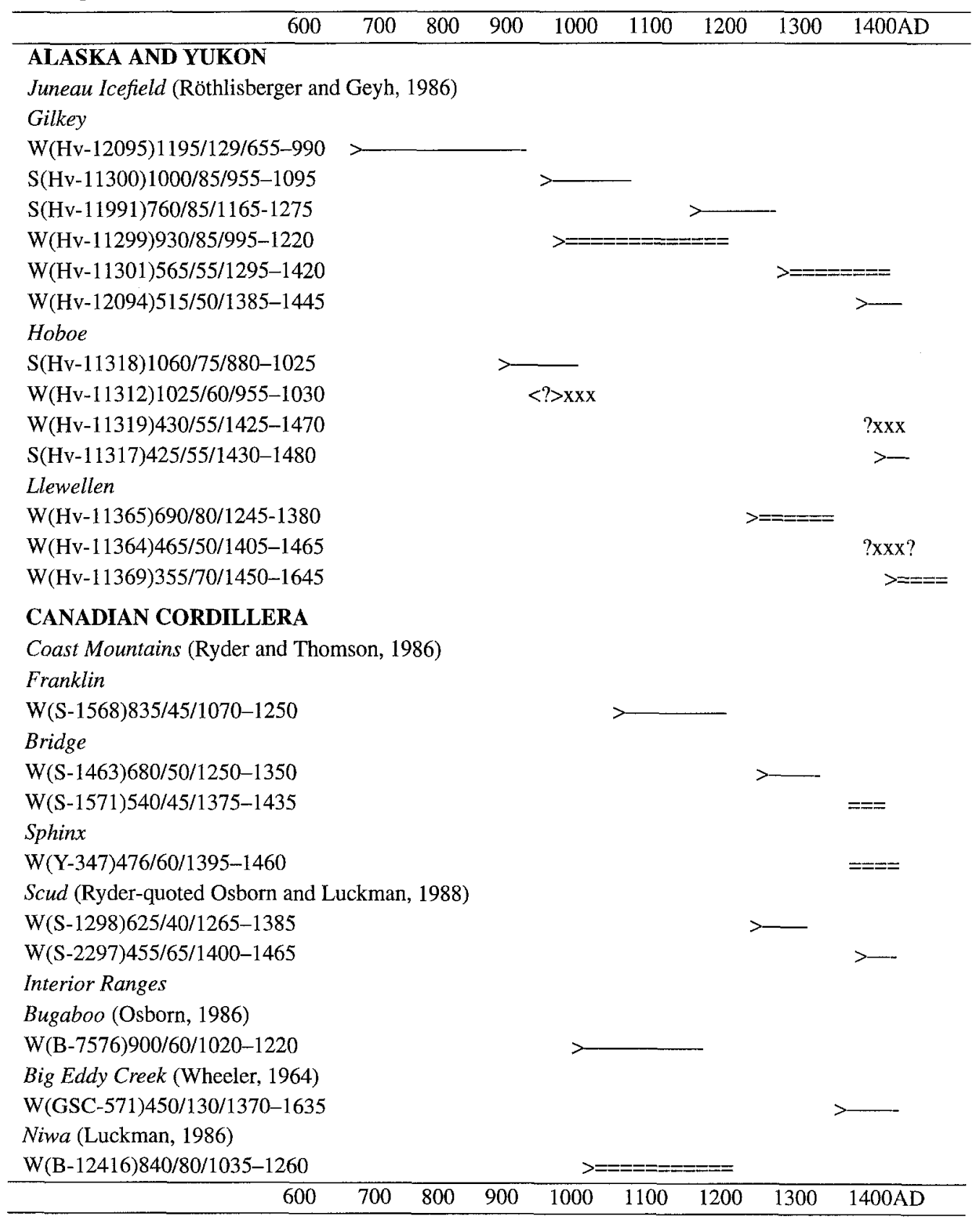

Note: $\mathrm{W}=$ wood, $\mathrm{S}=$ soil, $\mathrm{M}=$ moss, $\mathrm{P}=$ peat, $====$ in situ, $\mathrm{xxxx}=$ warm period. 
TABLE III: Continued

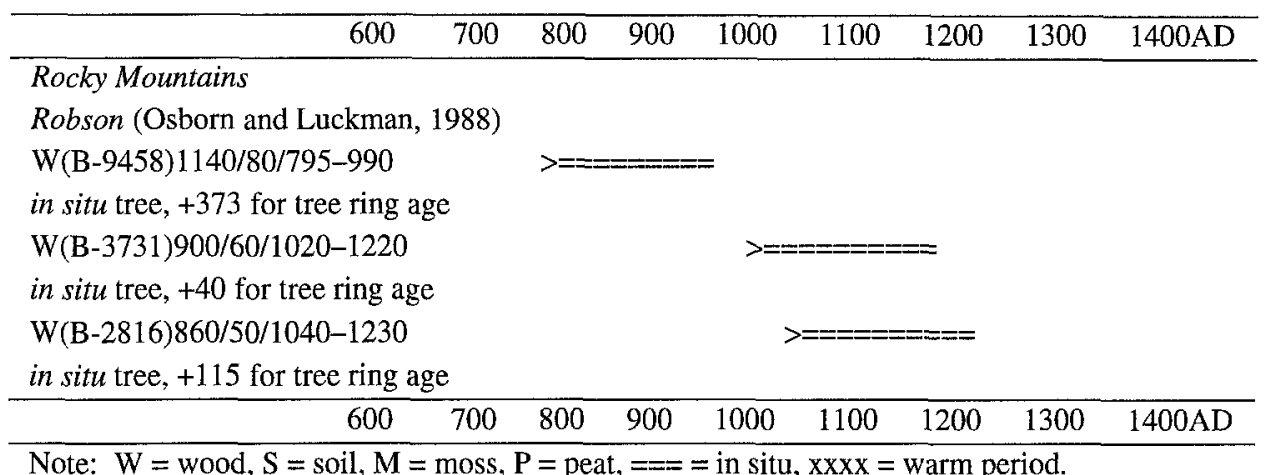

Note: $\mathrm{W}=$ wood, $\mathrm{S}=$ soil, $\mathrm{M}=$ moss, $\mathrm{P}=$ peat, $====$ in situ, $\mathrm{xxxx}=$ warm period.

by advances of the ice at the end of the MWP in 1245-1380 A.D. and again in 1450-1645 A.D. The original position of the wood fragment which was growing in 1405-1465 A.D. is unknown.

The dating of the top of a fossil soil in the right lateral moraine of the Hoboe (Hv-11318) provides a maximum age for the formation of the moraine above it by an advance preceeding the MWP between 880 A.D. and 1025 A.D., while warm periods between $955-1030$ A.D. and 1425-1470 A.D. may be indicated by samples of wood not in situ (Hv-11312 and Hv-11319). Another soil sample from the right lateral moraine (Hv-11317) seems to yield evidence of moraine formation around or after 1430-1480 A.D., after the MWP. None of these dates can be taken as close however. The evidence from the Gilkey is the most complete for the period of interest. The samples Hv-11299 and Hv-11301 both come from trees in situ, providing clearer evidence of the time of kill, but neither the number of rings displayed by these stumps nor the positions of the samples in relation to the rings were published.

\subsection{Canadian Cordillera}

The available evidence for the timing of the MWP in the Canadian Cordillera is also shown on Table III. On the basis of this assemblage of dates, Osborn and Luckman (1988) proposed that an advance period, which they termed the Cavell, occurred in the region shortly after $900 \mathrm{BP}$ An example of the type of evidence is the date for a moraine of the Bugaboo Glacier of $900 \pm 60 \mathrm{BP}$ (B-7576) obtained by Osborn (1986) from a tree limb, indicating an advance after 1020-1220 A.D.

Possible evidence of an earlier phase of expansion comes from Robson Glacier, where Hauser (1956) discovered a fossil spruce forest which had been felled by the ice and now lies beneath three metres of till (Luckman, 1986). Several of the trees have been sampled; the oldest (B-9458) has a calendar age of 795-990 A.D., 
but as it was 373 years old, the time it was overrun was in the period 1168-1363 A.D. (assuming that the innermost part was that sampled by ${ }^{14} \mathrm{C}$ ). Cross-dating of the rings may in due course reveal whether the glacier advance which killed it was coincident with those in the Alps or earlier. The fossil forest was growing in a thin paleosol above a fine-grained grey till. These units could represent soil formation during the MWP and a preceding glacial expansion. A similar picture comes from investigation of the lateral moraines of the Klinakini and Franklin Glaciers in the Coast Mountains (Ryder and Thomson, 1986), but no clear indications are available about the date of initiation of the paleosols.

Moraines formed in the later phases of the LIA are commonly so large in Canada as to conceal older and smaller deposits (Luckman, 1993). In Canada, as in Switzerland, dating of trees in situ is providing a more accurate approach to dating than would be possible on the basis of radiocarbon alone (Luckman, 1986). As many more stumps in situ are being uncovered by the current rapid recession, it may well become possible to reconstruct the timing of glacier fluctuations in the Canadian Cordillera more completely than can be done at present. (Luckman, 1993).

Evidence relating to the MWP has been found in widely scattered locations in North America. This suggests that the timing of the glacial advances preceeding and closing it may well have been in general accordance with that in the European Alps, but it is not yet sufficiently dense for it to be possible to identify regional variations satisfactorily.

\section{Tropical South America}

Well-dated evidence of the positions and extents of the tropical glaciers during and since the medieval centuries is sparse (Table IV), in part because many of them are small and in very remote places, difficult of access.

An advance of the Quelccaya Icecap, Cordillera Occidental, Peru, around 905 \pm 100 BP (I-8441) or 1000-1245 A.D., has been recognised on the basis of an exposure of peat bulldozed by ice readvance (Mercer and Palacios, 1977). Data from three glaciers in the Cordillera Blanca, Peru, was collected from exposures in lateral moraines by Röthlisberger and Geyh (1986). The oldest samples, from Huallacacocha, were of wood from trees in situ, which were killed sometime around or after 625-795 A.D. and 730-880 A.D. A further sample from a paleosol within the same moraine (Hv-8703) suggests the occurence of a later advance, closing the MWP, sometime after 1255-1335 A.D. The paleosol was $50-65 \mathrm{~cm}$ thick, indicating a long period of soil formation, with no disturbance from the ice.

Another paleosol sample from a lateral moraine of the Ocshapalca, with a date of $440 \pm 185 \mathrm{BP}$, gives a maximum age for the moraine above but is insufficiently precise to be very useful in supporting the Huallacacocha data. The single date of $500 \pm 80 \mathrm{BP}$ on peat from the Hichu-Khota valley, Cordillera Real, Bolivia, indicates moraine formation after 1375-1460 A.D. but does not preclude the possibility 
TABLE IV: Key dates relating to the glacier oscillations in South America. The numbers at the margin give the laboratory identification number, the $\mathrm{C} 14$ age and the calibrated age for $68 \%$ probability. Horizontal lines represent calibrated dates. The symbol $>$ indicates a maximum date; $<$ indicates a minimum date

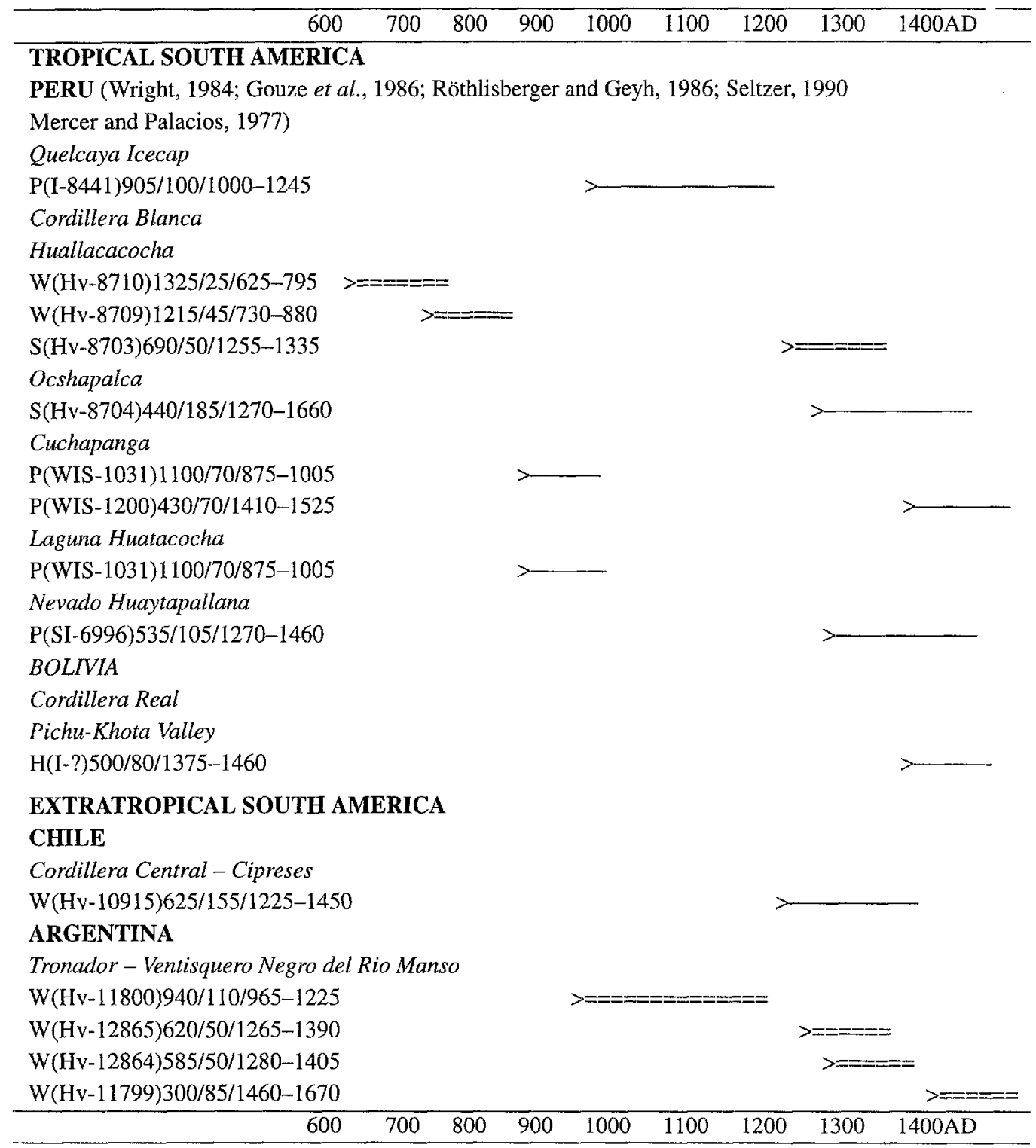


TABLE IV: Continued

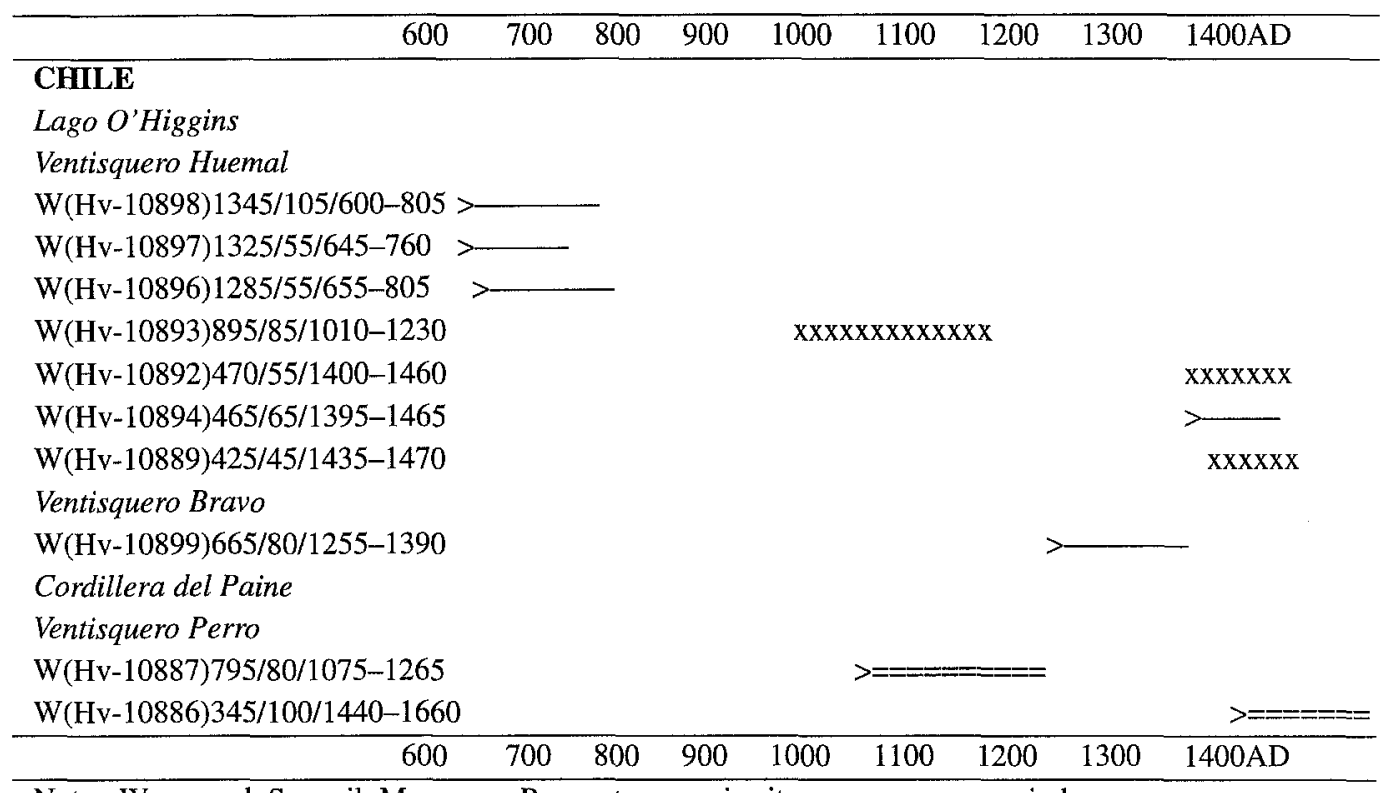

Note: $\mathrm{W}=$ wood, $\mathrm{S}=$ soil, $\mathrm{M}=$ moss, $\mathrm{P}=$ peat, $====$ in situ, $\mathrm{xxxx}=$ warm period.

that the LIA advances may have begun earlier. A certain amount of information may be obtained from investigation of the timing of trim-line formation. In the Cerros Cuchpanga, Peru, a clear trim-line about $100 \mathrm{~m}$ below the present ice-front separates bare rock and till from puna grassland. Ages of $1100 \pm 70 \mathrm{BP}$ (WIS-1031) and $430 \pm 70 \mathrm{BP}$ (WIS-1200) from the base of peat formed on outwash fans of two small glaciers have been interpreted as providing minimum dates for the same phase of glacial recession (Wright, 1984). The difference in age is attributed to outwash deposition continuing longer in the latter case. If this interpretation is correct, it serves to demonstrate very well the need for detailed field observations if false conclusions are to be avoided. Seltzer (1990) argued that dates from the base of peats near a trim-line at Nevado Huaytapallana (Si-6996) could also imply a phase of glaciation starting before 1300 A.D.

\section{Extra-Tropical South America}

Mercer $(1965,1968,1970,1976)$ was responsible for extensive field studies in South America. Further invesigations, concentrating particularly on lateral moraine exposures, were made by Röthlisberger (1985b, 1986). All the data on Table IV comes from Röthlisberger (1986). The dates selected for discussion are those with the clearest implications. 
In the moraines of the Ventisquero Negro or Rio Manso, on the south-east side of Cerro Tronador $\left(42^{\circ} \mathrm{S}\right)$ trunks of Nothofagus remain in situ. Röthlisberger concluded that four dates from the trees revealed in a river cut through the left lateral moraine provide evidence of several advances. The date of 1265-1390 A.D. (Hv-10915) from the Glaciar Cipreses, some $8^{\circ}$ latitude further north in the Cordillera Central, is not inconsistent with those from the Rio Manso, but came from wood which was not in situ.

Wood, in situ, from a fossil forest in paleosol $60-70 \mathrm{~cm}$ thick on bedrock, from a section through a lateral of the Ventisquero Bravo, in the O'Higgins region of Chile $\left(40^{\circ} \mathrm{S}\right)$ has an age of $665 \pm 80 \mathrm{BP}(\mathrm{Hv}-10899)$. Five more dates from Ventisquero Huemal, in the same region, are all from wood not in situ. Hv-10897 and $\mathrm{Hv}-10896$ come from wood in a fossil soil $100 \mathrm{~m}$ below the crest of a moraine and $100 \mathrm{~m}$ above the ice surface. The individual trunks were up to $40-50 \mathrm{~cm}$ in diameter. Each was taken to represent a glacial advance around or after the indicated ages. Röthlisberger considered that the date of $895 \pm 85 \mathrm{BP}$ (Hv-10893) and the three younger ones indicate times of minimum extension of the ice. All the wood samples were found some $300 \mathrm{~m}$ in front of the present glacier, its original position unknown, so the implications are not firmly based.

The final data available are from the Cordillera del Paine, Chile, at $51^{\circ} \mathrm{S}$. Both dates are from in situ trunks overridden by ice. These two different ages from a sheltered site were considered by Röthlisberger to represent separate advances.

Not one of these data sets includes a pair of bracketing dates for the same event, but the very different times at which trees were overridden by ice clearly shows that several advance phases occurred. These must have been separated by intervals during which the climate was suitable for tree growth. The general accordance of the results of investigations in very widely separated regions within South America is striking. There is no doubt that much more information could be obtained from further fieldwork among the many small sensitive glaciers in the Andes.

\section{New Zealand}

New Zealand data are shown on Table V. The glaciers concerned are all in South Island, either in Westland or in the much drier region to the east of the New Zealand Alps, in the Mount Cook or Rangitata areas.

Wood and fossil soils embedded in the superposed lateral moraines of the Tasman Glacier have yielded a considerable amount of information. On the basis of this a direct comparison has been made between the timing of the fluctuations of the Tasman front and that of the Aletsch during the last 1500 years (Gellatly et al.,1985). Interpretation of the evidence is not entirely straightforward because of the complexity of the moraine sections involved. The comparison with the Aletsch is persuasive but requires further support.

All the evidence from the Balfour Glacier comes from stumps in situ. A sample (Hv-10523), dated at 550-655 A.D., came from $10 \mathrm{~m}$ below the crest of a lateral 
TABLE V: Key dates relating to the glacier oscillations in New Zealand. The numbers at the margin give the laboratory identification number, the $\mathrm{C} 14$ age and the calibrated age for $68 \%$ probability. Horizontal lines represent calibrated dates. The symbol $>$ indicates a maximum date; $<$ indicates a minimum date

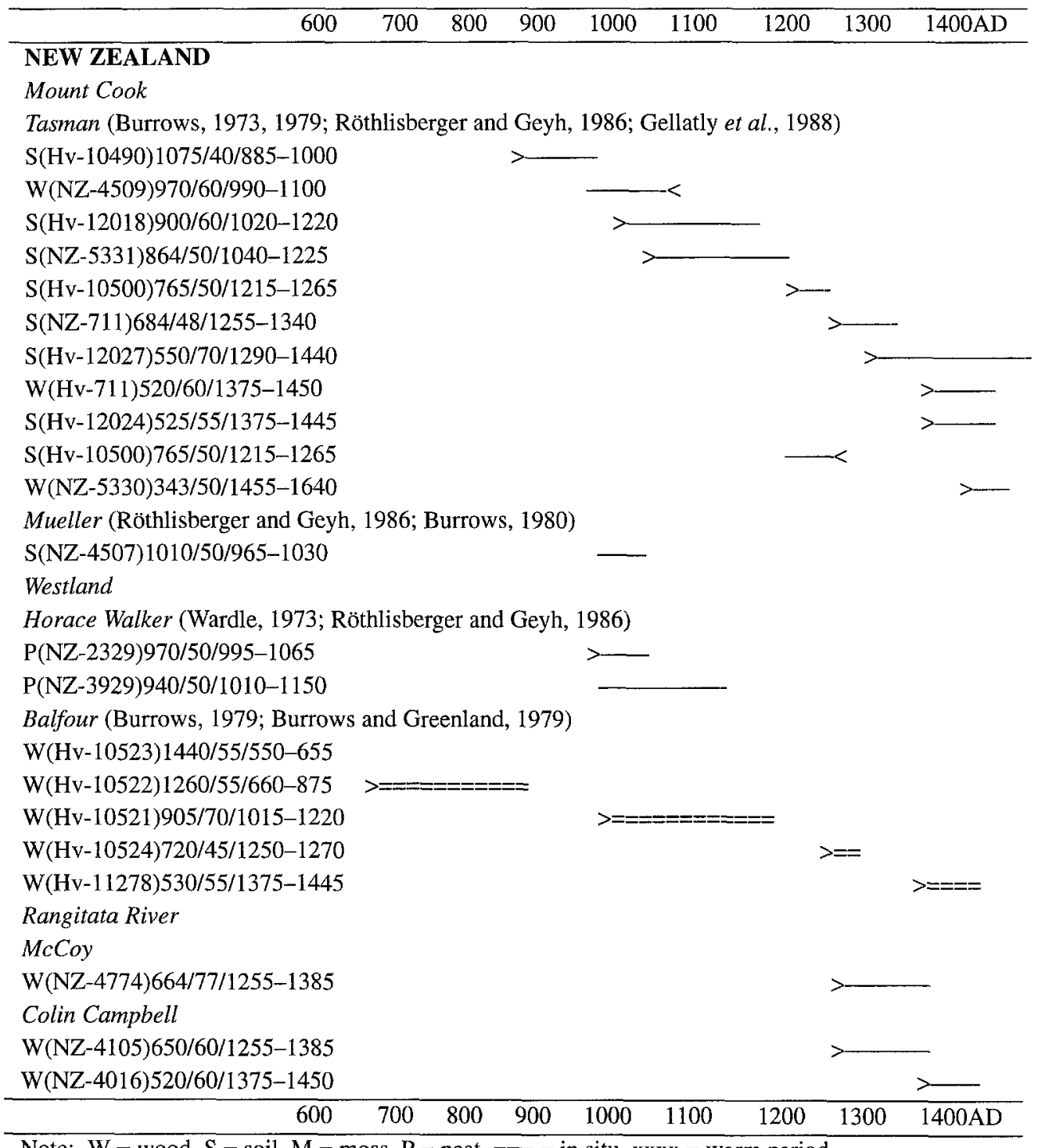

Note: $\mathrm{W}=$ wood, $\mathrm{S}=$ soil, $\mathrm{M}=$ moss, $\mathrm{P}=$ peat, === = in situ, $\mathrm{xxxx}=$ warm period.

moraine; Hv-10522, dated at 660-875 A.D., came from $100 \mathrm{~m}$ below the same crest. A sample (Hv-10521) was from a stump $15 \mathrm{~m}$ below the crest, and the two youngest were found $40 \mathrm{~m}$ and $50 \mathrm{~m}$ below it. It is reasonable to conclude that each one reflects an episode of shearing by the ice soon after the dates given 
by the samples, the lag depending on the unknown ages of the trees when they were killed. More clement conditions evidently intervened between the episodes of glacial expansion, during which trees could grow. It is unfortunate that Hv-10521 gives such a wide range of calendar dates as to make it impossible to determine whether it relates to an advance during the MWP or at the beginning of the LIA.

The accordance of the New Zealand data with the Swiss is rather clearer than that from other regions, although there is plenty of room for improvement and tighter control.

\section{Conclusion}

The first phase of the LIA began around the thirteenth century in all the regions for which there is evidence. The glacial phase preceding the MWP seems to have begun between the seventh and ninth centuries A.D. but is generally less securely dated and not dated at all in Canada. There are at least some indications of fluctuations in ice position in the course of the MWP in Norway, Alaska, and perhaps in extratropical South America and New Zealand, indicating that recession may have been interrupted by advances, perhaps of limited extent, as in the European Alps. The available evidence suggests that the MWP was global in extent and not uniform climatically. The glacial data needs to be considered in relation to that from other sources, but is of value in obtaining a more complete understanding of both the environment in the later medieval period and the possible causes of climatic change on the century time scale.

\section{Acknowledgements}

We wish to thank Jennifer Wyatt and Ian Agnew of the Department of Geography, Cambridge University and Simon Crowhurst of the Godwin Laboratory for drawing the diagrams.

\section{References}

Aeschlimann, H.: 1983, Zur Geschichte des Italienischen Mont Blanc Gebietes: Val Veni-Val FerretRuitor, Unpublished Dissertation, Geographischen Institut der Universität Zürich.

Aitchison, T. C. et al.: 1989, 'A Comparison of Methods Used for the Calibration of Radiocarbon Ages', Radiocarbon 31, 846-64.

Benedict, J. B.: 1976, 'Khumbu Glacier Series', Radiocarbon 18, 177-8.

Bless, R.: 1984, 'Beitrage zur Spät- und Postglazialen Geschichte der Gletscher im Nordöstlichen Mont Blanc Gebiet', Phys. Geogr. 15, 1-116.

Bradley, R. S. and Jones, P. D.: 1992a, 'When Was the "Little Ice Age"', in Mikami, T. (Ed.), Proceedings of the International Symposium on the Little Ice Age Climate, Tokyo Metropolitan University.

Bradley, R. S. and Jones, P. D.: 1992b, Climate since A.D. 1500, Routledge, London and New York.

Bradley, R. S. and Jones, P. D.: 1993, " "Little Ice Age" Summer Temperature Variations: Their Nature and Relevance to Recent Global Warming Trends', The Holocene 3, 367-76.

Burrows, C. J.: 1973, 'Studies of Some Glacial Moraines in New Zealand - 2. Ages of Moraines of the Mueller, Hooke and Tasman Glaciers (S79), New Zeal. Geol. Geophys. 16, 831-55. 
Burrows, C. J.: 1979, 'A Chronology for Cool-Climate Episodes in the Southern Hemisphere 120001000 yr. BP', Palaeogeogr. Palaeoclimatol. Palaeoecol. 27, 287-347.

Burrows, C. J.: 1980, 'Radiocarbon Dates for Post-Otiran Glacial Activity in the Mt. Cook Region, New Zealand', New Zeal. J. Geol. Geophys. 23, 239-48.

Burrows, C. J. and Greenland, D. E.: 1979, 'An Analysis of the Evidence for Climatic Change in New Zealand in the Last Thousand Years: Evidence from Diverse Natural Phenomena and from Instrumental Records', J. Roy. Soc. New Zeal. 9, 321-73.

Calkin, P. E.: 1988, 'Holocene Glaciation of Alaska (and Adjoining Yukon Territory, Canada)', Quatern. Sci. Rev. 7, 159-84.

Calkin, P. E. and Ellis, J. M.: 1981, 'A Cirque Glacier Chronology Based on Emergent Lichens and Mosses', J. Glaciol. 27, 512-5.

Clapperton, C. M. and Sugden, D. E.: 1988, 'Holocene Glacier Fluctuations in South America and Antarctica', Quatern. Sci. Rev. 7, 185-98.

Egan, C. P.: 1971, Contribution to the Late Neoglacial History of the Lynn Canal and Taku Valley Sections of the Alaska Boundary Range, PhD Dissertation, State University, East Lancing, Michigan.

Fushini, H.; 1977, 'Glaciation in the Khumbu Himal', Seppyo, J. Jap. Soc. Snow Ice 39, 60-7.

Fushini, H.: 1978, 'Glaciation in the Khumbu Himal', Seppyo, J. Jap. Soc. Snow Ice 40, 71-7.

Gellatly, A. F., Chinn, T. J. H., and Röthlisberger, F.: 1988, 'Holocene Glacier Variations in New Zealand: A Review', Quatern. Sci. Rev. 7, 227-42.

Griffey, N. J. and Matthews, J. A.: 1978, 'Major Neoglacial Expansion Episodes in Southern Norway: Evidence from Moraine Stratigraphy with C14 Dates on Buried Paleosols and Moss Layers', Geograf. Annal. 60(A), 73-96.

Grove, J. M.: 1985, 'The Timing of the Little Ice Age in Scandinavia', in Tooley, M. J. and Sheail, G. M. (eds.), The Climatic Scene, Allen and Unwin, London.

Grove, J. M.: 1988, The Little Ice Age, Methuen, London and New York.

Grove, J. M. and Orombelli, G.: 'The Southern Region of Europe; the Alps, Italy and the Pyrenees', in Boulton, G. S. and Mason, P. (eds.), Evaluation of Climate Proxy Data in Relation to the European Holocene, Special issue: ESF Project European Climate and Man. Paläoklimaforsch. Palaoclim. Res., in press.

Gouze, P., et al.: 1986, 'Interpretation Paleoclimatique des Oscillations des Glaciers au Cours des 20 Derniers Millenaires dans les Regions Tropicales: Example des Andes Boliviennes', Compte Rend. L'Acad. Sci. Paris 303 (II), 219-23.

Heuser, C. J.: 1956, 'Postglacial Environments in the Canadian Rocky Mountains', Ecol. Monogr. 26, 253-302.

Holzhauser, P.: 1984a, 'Zur Geschichte der Aletschgletscher und des Fieschergletscher', Phys. Geogr. $13,1-448$.

Holzhauser, P.: 1988, 'Methoden zur Rekonstruktion von Gletscherschwankungen', Die Alpen 64, $135-65$.

Holzhauser, P.: 1984b, 'Rekonstruktion von Gletscherschwankungen mit Hilfe Fossiler Holzer', Geograph. Helv. 39, 3-15.

Karlén, W.: 1988, 'Scandinavian Glacial and Climatic Fluctuations during the Holocene', Quatern. Sci. Rev. 7, 100-209.

Lamb, H. H.: 1965, 'The Early Medieval Warm Period and Its Sequel', Paleogeogr, Paleoclimatol., Paleoecol. 1, 13-37.

Luckman, B. H. and Osborn, G. D.: 1979, 'Holocene Glacier Fluctuations in the Middle Canadian Rocky Mountains', Quatern. Res. 25, 10-24.

Luckmann, B. H.: 1986, 'Reconstruction of Little Ice Age Events in the Canadian Rocky Mountains', Geograph. Phys. Quatern. XL, 17-28.

Luckman, B. H.: 1993, 'Neoglacial Glacier Fluctuations in the Canadian Rockies', Quatern. Res. 39, 144-53.

Lütschg, O.: 1926, 'Über Niederschlag und Abfluss im Hochgebirge, Sonderdarstellung des Mattmarkgebietes', Schweizerischer Wasserwirtschaftverband, Verbandschrift C14, Veröffentlichung der Schweizerischen Meteorologischen Zentralanstalt in Zürich, Zürich Sekretariat des Schweizerischen Wasserwirtschaftstverbandes. 
Kinzl, H.: 1932, 'Die Grössten Nacheiszeitlichen Gletschervorstösse in den Schweizer Alpen und in der Mont-Blanc-Gruppe', Zeitschr. Gletscherk. 20, 269-397.

Mann, D. H.: 1986, 'Reliability of a Fjord Glacier's Fluctuations for Paleoclimatic Reconstruction', Quatern. Res. 25, 10-24.

Matthews, J. A.: 1984, 'Limitations of C14 Dates from Buried Soils in Reconstructing Glacier Variations and Holocene Climate', in Morner, N. A. and Karlén, W. (eds.), Climatic Changes on a Yearly to Millennial Basis: Geological, Historical and Instrumental Records, 281-90.

Matthews, J. A.: 1985, '14 C Dating of Paleosols, Pollen Analysis and Landscape Change: Studies from Low- and Mid-Alpine Belts of Southern Norway', in Boerdman, J. (ed.), Soils and Quaternary Landscape Evolution, John Wiley London, pp. 87-116.

Mayr, F.: 1964, 'Untersuchungen über Ausmass und Folgen der Klima- und Gletscherswankungen seit dem Beginn der postglazialen Wärmezeit', Zeitschr. Geomorphol. 8, 257-85.

Mercer, J. H.: 1965, 'Glacier Variations in Southern Patagonia', Geograph. Rev. 55, 390-413.

Mercer, J. H.: 1968, 'Variations of Some Patagonian Glaciers since the Late Glacial I', Amer. J. Sci. 266, 1-25.

Mercer, J. H.: 1970, 'Variations of Some Patagonian Glaciers since the Late Glacial II', Amer. J. Sci 269, 91-109.

Mercer, J. H.: 1976, 'Glacial History of Southernmost South America', Quatern. Res. 6, 125-66.

Mercer, J. H. and Palacios, O.: 1977, 'Radiocarbon Dating of the Last Glaciation in Peru', Geol. 5, $600-4$.

Miller, G. H.: 1973, 'Late Quaternary Glacial and Climatic History of Northern Cumberland Peninsula, East Baffin Island, NWT, Canada', Quatern. Res. 3, 561-83.

Nesje, A.: 1991, 'Holocene Glacial and Climatic History of the Jostedalen Region, Western Norway' Evidence from Lake Sediments and Terrestial Deposits', Quatern Sci. Rev. 10, 87-114.

Nesje, A. and Dahl, S. D.: 1991, 'Holocene Variations of Blaisen, Hardangerjoklen, Central South Norway', Quatern. Res. 35, 25-40.

Nesje, A. and Rye, N.: 1993, 'Late Holocene Glacial Activity at Sandskard Fonna, Jostedalsbreen Area, Western Norway', Norsk Geogr. Tidsskr. 47, 21-8.

Nesje, A. et al.: 1991, 'Holocene Glacial and Climatic History of the Jostedalsbreen Region, Western Norway; Evidence from Lake Sediments and Terrestial Deposits', Quatern. Sci. Rev. 10, 87-114.

Oeschger, H. and Röthlisberger, H.: 1961, 'Datierung Eines Ehemaligen Standes des Aletschgletschers durch Radioaktivitätsmessung an Holsproben und Bemerkungen zu Holsfunden an Weiteren Gletschern', Zeitschr. Gletscherk. Glazialgeol. 4, 191-205.

Orombelli, G. and Porter, S. C.: 1982, 'Late Holocene Fluctuations of Brenva Glacier', Geogr. Fis. Dinam. Quatern. 5, 14-37.

Osborn, G.: 1986, 'Lateral Moraine Stratigraphy and Neoglacial History of Bugaboo Glacier, British Columbia', Quatern. Res. 26, 171-8.

Osborn, G. and Luckman, B. H.: 1988, 'Holocene Glacier Fluctuations in the Canadian Cordillera (Alberta and British Columbia)', Quatern. Sci. Rev. 7, 115-28.

Porter, S. C.: 1981, 'Lichenometric Studies in the Cascade Range of Washington: Establishment of Rhizocarpon Geographicum Growth Curves on Mt. Rainier', Arc. Alp. Res. 13, 11-23.

Porter, S. C. and Orombelli, G.: 1986, 'Glacier Contraction during the Middle Holocene in the Western Italian Alps: Evidence and Implications', Geol. 13, 296-8.

Rabot, C.: 1902, 'Essai de Chronologie des Variations Glaciaires', Bull. Geogr. Histor. Descript. 285-327.

Röthlisberger, F.: 1986, 10000 Jahre Gletschergeschichte der Erde, Mit einem Beitrag von M. A. Geyh, Sauerländer, Aarau und Frankfurt am Main.

Röthlisberger, F. and Schneebeli, W.: 1979, 'Genesis of Lateral Moraine Complexes, Demonstrated by Fossil Soils and Trunks: Indicators of Postglacial Climatic Fluctuations', in Schluchter, E. (ed.), Moraines and Varves, Balkema, Rotterdam, pp. 387-419.

Röthlisberger, F., et al.: 1980, 'Holocene climatic Fluctuations. Radiocarbon Dating of Fossil Soils (fAh) and Wood from Moraines and Glaciers in the Alps', Geogr. Helv. 35, 21-52.

Röthlisberger, F. and Geyh, M. A.: 1985a, 'Glacier Variations in the Himalayas and Karakorum', Zeitschr. Gletscher, Glazialgeol. 21, 237-49.

Röthlisberger, F. and Geyh, M. A.: 1985b, 'Gletscherschwankungen der Nacheiszeit in der Cordillera 
Blanca (Peru) und den Südlichen Anden Chiles und Argentiniens', Zentralbl. Geol. Paleoontol. 11, 1611-3.

Ryder, J. M. and Thomson, B.: 1986, 'Neoglaciation in the Southern Coast Mountains of British Columbia: Chronology of Events Prior to the Late Neoglacial Maximum', Canad. J. Earth Sci. 23, 273-87.

Sacco, F.: 1917, 'I Ghiacciai Italiani del Gruppo Monte Bianco', Boll. Comit. Glaciol. Ital. Ser. 2. 3, 21-102.

Seltzer, G. O.: 1990, 'Recent Glacial History and Paleoclimate of the Peruvian-Bolivian Andes', Quatern. Sci. Rev. 9, 137-52.

Stuiver, M. and Pearson, G. W.: 1986, 'High Precision Calibration of the Radiocarbon Timescale A.D. 1950-500 B.C.', Radiocarbon 28, 805-38.

Stuiver, M. and Pearson, G. W.: 1993, 'High-Precision Bidecadal Calibration of the Radiocarbon Timescale A.D. 1950-500 B.C.', Radiocarbon 35, 1-23.

Suess, H. E.: 1970, 'Bristlecone Pine Calibration of the Radiocarbon Timescale 5200 B.C. to Present', in Olson, I. U. (ed.), Radiocarbon Variations and Absolute Chronology, Interscience, New York.

Tuthill, S. J., Field, W. O., and Clayton, L.: 1966, 'Past Earthquake Studies of the Sherman and Sheridan Glaciers', in The Great Alaskan Earthquakes of 1964 (Hydrology Volume), National Academy of Sciences, Washington, D. C. Publication 163, pp. 318-28.

Villalba, R.: 1990, 'Climatic Fluctuations in Northern Patagonia during the Last Thousand Years as Inferred from 'Tree Rings', Quatern Res. 34, 346-60.

Wardle, P,: 1973, 'Variations of Glaciers in Westland National Park and the Hooker Range', New Zeal. J. Botany 11, 349-88.

Wheeler, J. O.: 1964, 'Selkirk and Monash Mountains: Recent Glacier Fluctuations', Canad. Geophys. Bull. 17, 1267.

Williams, V. S.: 1983, 'Present and Former Equilibrium Line Altitudes near Mt. Everest, Nepal and Tibet', Arc. Alp. Res. 15, 201-11.

Willis, E. H., Munnich, K. O., and Tauber, H.: 1960, 'The Variations in Atmospheric Radiocarbon Activity over the Past 1800 Years', Amer. J. Sci. Radiocarb. Suppl. 2, 1-4.

Worsley, P. and Alexander, M.: 1975, 'Neoglacial Paleoenvironmental Change at Engabreen, Svartisen, Holandsfiord, North Norway', Norges Geol. Underokelse 321, 37-66.

Wright, H. E.: 1984, 'Late Glacial and Late Holocene Moraines in the Cerros Cuchpanga, Central Peru', Quatern. Res. 21, 275-85.

Zumbühl, H. J. and Holzhauser, H.: 1990, 'Alpengletscher in den Kleinen Eiszeit', Geogr Bern. 31, 3-36.

(Received 22 September, 1992; in revised form 12 October, 1993). 